19. Moore, E. S., Fine, B. P., Satrosook, S. S., Vergel, Z. M., and Edelmann, C. M., Jr.: Renal reabsorption of bicarbonate in puppies: Effect of intracellular volume contraction on the renal threshold for bicarbonate. Pediat. Res., 6: 859 (1972).

20. Parkenson, M. L., Lubowitz, H., White, R. S., and Bricker, N. S.: On the influence of extracellular fluid volume expansion on bicarbonate reabsorption in the rat. J. Clin. Invest., 48: 1754 (1969).

21. Potter, D., Jarrah, A., Sakai, T., Harrah, J., and Holliday, M. A.: Character of function and size in kidney during normal growth of rats. Pediat. Res., 3: 51 (1969).

22. Rector, F. C., Jr., Bloomer, H. A., and Seldin, D. W.: Effects of K deficiency on reabsorption of bicarbonate in the proximal tubule of the rat. J. Clin. Invest., 43: 1976 (1964)

23. Rector, F. C., Jr., Seldin, D. W., Roberts, A. D., Jr., and Smith, J. S.: The role of plasma $\mathrm{CO}_{2}$ tension and carbonic anhydrase activity in the renal reabsorption of bicarbonate. J. Clin. Invest., 39: 1706 (1960)

24. Robillard, J. E., Kulvinskas, C., Sessions, C., Burmeister, L., and Smith, F G., Jr.: Maturational changes in the fetal glomerular filtration rate. Amer. J. Obstet. Gynecol., 122: 601 (1975).

25. Robillard, J. E., Sessions, C., Kennedy, R., Burmeister, L., and Smith, T, G. Jr.: Renal carbonic anhydrase activity in the chronic fetal lamb. (In preparation.)

26. Robillard, J. E., Smith, F. G., Jr., Kulvinskas, C., and Braden, E.: Carbonic anhydrase function in the fetal kidney [Abstr.]. Pediat. Res., 7: 188 (1973).

27. Saloman, L. L., and Johnson, J. E.: Enzymatic microdetermination of glucose in blood and urine. Anal. Chem., 31: 453 (1959).

28. Seldin, D. W., and Rector, F. C., Jr.: The generation and maintenance of metabolic acidosis. Kidney Intern., 1: 306 (1972).

29. Siggaard Andersen, O., and Engel, K.: A new acid-base nomogram methou for the calculation of the relevant blood acid-base data. Scand. J. Clin. Invest., 12: 177 (1960)

30. Smith, F. G., Jr., and Schwartz, A.: Response of the intact lamb fetus to acidosis. Amer. J. Obstet. Gynecol., 106: 52 (1970).

31. Smith, F. G., Jr., Tinglof, B., and Adams, F. H.: Renal phosphate clearance and bicarbonate excretion in the fetal lamb [Abstr.]. J. Pediat., 67: 955 (1965).

32. Solomon, S.: Absolute rates of sodium and potassium reabsorption by proximal tubule of immature rats. Biol. Neonate, 25: 340 (1974).

33. Spitzer, A., and Brandis, M.: Functional and morphologic maturation of the superficial nephrons. J. Clin. Invest., 53: 279 (1974).

34. Spitzer, A., and Windhager, E. E.: Effect of peritubular oncotic pressure changes on proximal tubular fluid reabsorption. Amer. J. Physiol., 218 $1188(1970)$

35. Stein, J. H., and Reineck, H. J.: Effect of alterations in extracellular fluid volume on segmental sodium transport. Physiol. Rev., 55: 127 (1975).

36. Steinmetz, P. R.: Cellular mechanisms of urinary acidification. Physiol. Rev., 54: $890(1974)$.

37. Suki, W. N., Hebert, C. S., Stinebaugh, B. J, Martinez-Maldonado, M., and Eknogan, G.: Effects of glucose on bicarbonate reabsorption in the dog kiuney. J. Clin. Invest., 54: 1 (1974).

38. Svenningsen, N. W.: Renal acid-base titration studies in infants with and without metabolic acidosis in the postneonatal period. Pediat. Res., 8: 659 (1974).

39. Tsoulos, N. G.: Comparison of glucose, fructose and $\mathrm{O}_{2}$ uptakes by fetuses of fed and starved ewes. Amer. J. Physiol.,'221: 234 (1971).

40. Van Slyke, D. D., and Neill, J. M.: The determination of gases in blood and other solutions by vacuum extraction and manometric measurement. J. Biol. Chem., 61: 523 (1924).

41. Vaughn, D., Kirschbaum, T. H., Bersentes, T., Dilts, P. V., Jr., and Assali, N. S.: Fetal and neonatal response to acid loading in the sheep. J. Appt Physiol., 24: 135 (1968)

42. Widdowson, E. M. Growth and composition of the fetus and newborn. In: N. S. Assali: Biology of Gestation, p. 1 (Academic Press, New York, 1968).

43. Xylocaine, Astra Pharmaceutical Products, Inc., Worchester, Mass.

44. Harvard Apparatus, Millis, Mass.

45. Baxter Laboratories.

46. Glofil, Abbott Laboratories, North Chicago, III.

47. Radiometer, London Co., Cleveland, Ohio.

48. Instrument Laboratory, Lexington, Mass.

49. Buchler Instruments, Inc., Fort Lee, N. J,

50. Advanced Instruments, Inc., Needham Ifeights, Mass.

51. Beckman Instruments, Inc., Palo Alto, Calif.

52. A preliminary report of these findings was presented at the 1975 Annual Meeting of the American Pediatric Society - The Society for Pediatric Research (Pediat Res., 9: 378 (1975).

53. This research was supported by Research Grant No HD 08953 from the National Institute of Child Health and Human Development and Research Grant MA-5652 from the Canadian Medical Research Council.

54. Requests for reprints should be addressed to: J. E. Robillard, M.D.. Depart ment of Pediatrics, Division of Nephrology, University of Iowa Hospital and Clinics, Iowa City, Iowa, 52240 (USA).

55. Received for publication February 18, 1976

56. Accepted for publication September 30, 1976.

\title{
Cyclic Nucleotide Phosphodiesterase Activities of the Fetal and Mature Human Cerebral Cortex
}

\author{
ELLEN S. KANG \\ WITH THE TECHNICAL ASSISTANCE OF DANIEL L. ELLSWORTH \\ Department of Biochemistry, St. Jude Children's Research Hospital, and the Department of Pediatrics, University of \\ Tennessee Center for the Health Sciences, Memphis, Tennesse', USA
}

\section{Summary}

Phosphodiesterase activities were examined in the supernatant and pellet fractions of a $30,000 \times g$ preparation of brain tissues from human fetuses and young adults. Differences in total activity and distribution of the high and low $K_{m}$ activity enzymes for adenosine and guanosine $3^{\prime}, 5^{\prime}$-monophosphate (cyclic AMP and cyclic GMP, respectively) were found. The mature cortex had 10 times more activity than the fetal brain for cyclic AMP hydrolysis and 15-20 times more activity for cyclic GMIP hydrolysis. In the fetus, more activity for both nucleotides at both high and low concentrations is associated with the supernatant fraction. With maturity, a shift in localization of high $\mathbf{K}_{\mathrm{m}}$ activity for cyclic GMP and low $K_{m}$ activities for both nucleotides to the particulate fraction is observed.

Michaelis constants for both mature and immature brains are similar. The $\mathrm{K}_{\mathrm{m}}$ values for cyclic $\mathrm{AMP}$ are $10^{-4}$ and $10^{-5} \mathrm{M}$ and $10^{-4}$ and $10^{-6} M$ for cyclic GMP. The $V_{\max }$ values differed by a factor of 10 between the high $K_{m}$ and the low $K_{m}$ forms for each substrate. 
Differences were observed between the fetus and the adult when the hydrolysis of one nucleotide was measured in the presence of varying amounts of the other nucleotide. Low concentrations of either nucleotide stimulated the hydrolysis of low concentrations of the other in the adult whereas, in the fetus, low concentrations of cyclic AMP inhibited cyclic GNP hydrolysis. At higher concentrations of either nucleotide, the addition of the other over a wide range of concentrations resulted in inhibition which was exaggerated in the fetus.

\section{Speculation}

Differences in responsiveness to modulators observed between fetal and adult enzymes suggest the possibility that these enzymes occur as isozymes. Substantiation of this possibility will require the separation of these enzymes in pure form.

Considerable evidence exists which suggests that the two naturally occurring cyclic nucleotides, cyclic AMP and cyclic GMP, are extensively involved in the regulation of the development and function of the nervous system. For instance, in model systems, ( $l$ ) the induction of enzymes involved in neurotransmission has been demonstrated for the adenosine nucleotide (9, $23,24,26,30),(2)$ control of growth and differentiation of neuronal tissuc appear to be highly responsive to changes of the intracellular concentrations of cyclic AMP (29, 30, 45), and (3) the putative neurotransmitters elicit changes in the concentrations of the cyclic nucleotides during neurotransmission as determined by iontophoretic studies in both eentral and peripheral preparations $(15,20)$. In addition, evidence is also accumulating that cyclic AMP and cyclic GNIP facilitate opposing effects in a number of tissues including nervous tissue $(13,38)$.

The concentration of these cyclic nucleotides in tissues are determined in part by the rate of their hydrolysis by specific phosphodiesterases. Under a common stimulus, the intracellular metabolism of responsive cells could vary widely depending on the functional status of the several forms of phosphodiesterase (PIIE) which have been described in mammalian tissues.

In animals, developmental studies by Schmidt et al. (35) and Weiss (46) showed the presence of PDE in the brain of the newborn rat which increased to maturity levels by 15-23 days. Approximately $50 \%$ of the total PDE activity was associated with the particulate fraction according to the data of Weiss and Costa (47), whereas Schmidt and his associates found that the majority of the activity was located in the supernatant at a ratio of $4: 1$ for the particulate fractions at all ages studied. These studies were performed under experimental conditions which fail to account for the multiple forms of PI)E since substrate was limited to cyclic AMP at concentrations of $10^{-3}$ and $10^{-4} \mathrm{M}$. Strada et al. (39) reinvestigated the postnatal development of this enzyme in the rat using physical separation methods in conjunction with kinetic analyses. The large total postnatal increase seen in the rat cerebrum was found to be due primarily to a 6 -fold increase in the activity of the high $\mathrm{K}_{m}$ enzyme. The low $\mathrm{K}_{\mathrm{m}}$ enzyme increased about 2.5 -fold in activity during the same period.

It should be emphasized that age-function studies of the brain have been limited to the newborn and 60-100-day-old rat. Since maximum alterations in adaptive responsiveness to a variety of stimuli are observed between fetal and mature organs, the activities of the kinetically definable forms of PDE were examined in the cerebral cortices of the human fetus and adult. In addition, the effect of a variety of modulators of PDE activity was examined in the mature cortex and, in some instances, in the immature cortex.

\section{MATERIALS AND METHODS}

\section{CLINICAL MATERIALS}

Tissues for enzyme studies were collected at autopsy and kept frozen at $-20^{\circ}$ or $-80^{\circ}$ until analysis. Pertinent clinical features and the time elapsing between death or the expulsion of the fetus and the beginning of the postmortem examination for each subject are listed in Table 1 . All autopsies were conducted routinely with the removal of the abdominal viscera preceding the removal of the brain. PDE assays were dene on representative sections of frontal cortex containing both white and gray matter. All tissues were obtained with the informed consent of the responsible next of kin.

\section{EXPERIMENTAL METHODS}

Phosphodiesterase activity was assayed in the supernatant and particulate fractions of tissues which were homogenized in 3 volumes of glass-distilled water, freeze-thawed rapidly three times, spun at $30,000 \times g\left(0-4^{\circ}\right)$ for $30 \mathrm{~min}$, and dialyzed overnight in $20 \mathrm{mM}$ Tris buffer, pH 7.5 , at $4^{\circ}$. PIDE activity observed in the undialyzed fraction of a $30,000 \times g$ homogenate of cortex from a 56 -year-old male subject was $86.6 \mathrm{nmol} / \mathrm{mg} / \mathrm{min}$ whereas the dialyzed fraction was 93.8. This increase in activity is probably due to the removal of endogenous substrates. Amounts of protein used for lincarity over a 10 -min period were $50-100 \mu \mathrm{g}$ in $100 \mu \mathrm{l}$ total volume for cvelic AMP PIDE and $25-$ $50 \mu \mathrm{g}$ protein for cyclic GMP PDE. Incubation was for $10 \mathrm{~min}$ for specific activities and $1 \mathrm{~min}$ for kinetic studies at $3+-36^{\circ}$. The divalent cation requirement was met by $\mathrm{Mn}^{++}$at at final concentration of $0.1 \mathrm{mM}$ and the reaction was conducted in $40 \mathrm{mM}$ Tris buffer, pH 7.t. The two-step isotopic method of Thompson and Appleman (44) was used. Substrate concentrations varied over a range of $2 \times 10^{-3}$ to $10^{-8} \mathrm{M}$. Theophylline was used at final concentrations of 0.9 to $7.5 \mathrm{mM}$. Final concentrations of imidazole were 10,20 , and $40 \mathrm{mM}$. Activator effects were studied with and without the addition of $10 \mu \mathrm{g}$ partially purified protein from bovine brain, which was a gift from Dr. L. Liu. The percentage of conversion of labeled substrate to the 5 -derivative was determined in an aliquot of the supernatant after resin precipitation in Bray's solution in a spectrophotometer.

To determine the effect of differences in PDE activity due to variation in time between death and collection of tissues, cerebral cortices from single rats were frozen immediately and at 3 , 5 , and $24 \mathrm{hr}$ after death, during which interval the intact carcass of each animal was refrigerated at $4^{\circ}$. All tissues were processed simultaneously for PDE measurements.

Adenosine $3^{\prime}, 5^{\prime}$-cyclic $\left[8^{3} \mathrm{H}\right]$ phosphate was purchased from Schwarz-Mann and guanosine $3^{\prime}, 5^{\prime}$-cyclic $\left[{ }^{3} \mathrm{H}-G \mid \mathrm{phosphate}\right.$ was obtained from New England Nuclear. Isotopes were further purified by chromatography on thin layer plates of cellulose in 2 propanol, ammonia, water $(7: 1: 2)$ before use. All other chemicals were of reagent grade. Protein was determined by the method of Lowry with bovine serum albumin as a standard (25). DNA wats measured by the diphenylamine method of Burton (7).

\section{RESULTS}

Since our samples were obtained at autopsy and the specific diseases, agonal conditions, and ages of our subjects varied considerably, the stability of the enzyme to storage effects and a common basis for comparison of enzyme activity had to be determined.

The specific activities observed for cyclic AMP hydrolysis of individual rat brains collected after varying periods of storage at $4^{\circ}$ are presented in Table 2 . No change in the specific activity of PDE was noted in tissues obtained from intact animals refrigerated for up to $24 \mathrm{hr}$. This observation is in agreement with the published literature which indicates that the crude enzyme is remarkably stable during storage (2).

Activity was based on DNA for the following reasons. (1) Increase in cellular protein, RNA, lipid, and witer content of the cortex continues throughout the process of maturation which extends through adolescence (19). (2) Neuroblastic proliferation is completed by 20 weeks of gestational age in man and glial proliferation by the end of the first postnatal year $(11,49)$. 
Table 1. Clinical information of subjects

\begin{tabular}{|c|c|}
\hline Subject & Information \\
\hline 1 & $\begin{array}{l}\text { 14-weck male fetus, spontaneously aborted, twin of subject } \\
2,2 \mathrm{hr}^{1}\end{array}$ \\
\hline 2 & $\begin{array}{l}\text { 14-week female fetus, spontaneously aborted, twin of sub. } \\
\text { ject } 1,2 \mathrm{hr}^{1}\end{array}$ \\
\hline 3 & 18-week male fetus, spontaneously aborted, $2 \mathrm{hr}^{1}$ \\
\hline 4 & 18-week male fetus, spontancously aborted, $2-3 \mathrm{hr}^{1}$ \\
\hline 5 & 19-2()-week fetus, spontaneously aborted, several hours' \\
\hline 6 & $\begin{array}{l}\text { 15-year-old male, mental retardation, polycystic kidneys, } \\
\text { uremia, } 12 \mathrm{hr}^{1}\end{array}$ \\
\hline 7 & $\begin{array}{l}\text { 18-year-old male, treated acute lymphocytic leukemia, } \\
\text { sepsis, } 12-24 \mathrm{hr}^{\prime}\end{array}$ \\
\hline 8 & $\begin{array}{l}\text { 19-year-old male, acute hemorrhage from traumatic chest } \\
\text { wound, } 12 \mathrm{hr}^{1}\end{array}$ \\
\hline
\end{tabular}

${ }^{1}$ Hours elapsing between death and autopsy. For fetuses, elapsed time from expulsion of fetus to collection of tissues.

Table 2. Effect of delay in freezing of cercebral cortical tissues on phosphodiesterase activity.

Specific activity, nmol/mg protein/ $\min ^{2}$

\begin{tabular}{ccc}
\cline { 2 - 3 } Interval between death ${ }^{1}$ and & $50 \mu \mathrm{M}$ cyclic & $1 \mathrm{mM}$ cyclic \\
freezing of tissues, hr $(n=1)$ & AMP & AMP \\
\hline 0 & 3.25 & 69.97 \\
3 & 3.48 & 74.92 \\
5 & 3.40 & 70.34 \\
24 & 3.58 & 75.91 \\
\hline
\end{tabular}

'Sprague-Dawley rats of approximately same weight killed by ether anesthesia before removal of brain and freezing of tissue. Carcasses kept intact at $4^{\circ}$ for the indicated duration.

2 Averages of duplicate determinations.

Thus, the DNA content of the human cerebral cortex is essentially constant after approximately the first year of life. Activity per unit DNA may, therefore, be considered most representative of changes in cellular activity in the human cortex from subjects of widely different ages, reflecting largely neuroblastic activity in the fetus and combined neuroblastic and glial activity after the first year of life.

\section{COMPARISON OF TOTAL ACTIVITY AND DISTRIBUTION OF PIIOSPHODIESTERASE ACTIVITIES}

\section{CYCLIC AMP PDE ACTIVITY}

Differences in distribution and total activity are found between the fetal and mature cortex. Maturation is accompanied by a 10 -fold increase in activity for both the high and low $\mathrm{K}_{\mathrm{m}}$ enzymes. Most of the high $\mathrm{K}_{m}$ activity is in the supernatant fraction in both fetal and mature brains. However, more low $\mathrm{K}_{\mathrm{m}}$ activity is present in the pellet in the mature cortex, in contrast to the fetal brain, where more is located in the supernatant fraction (see Fig. 1). Activities based on brain weight are tabulated in Tables 3 and 4 .

\section{CYCLIC GMP PDE ACTIVITY}

Differences in total activity and distribution are found again. Maturation results in a 15-20-fold increase in activity for both high and low $\mathrm{K}_{\mathrm{m}}$ enzymes. In the mature brain, most of the high and low $K_{m}$ activity is located in the pellet fraction, whereas these activities are located predominantly in the supernatant in the fetal brain (see Fig. 2).

\section{MICHAELIS CONSTANTS}

Nonlinear figures were obtained when the double reciprocals of substrate concentration and activity or velocity were plotted

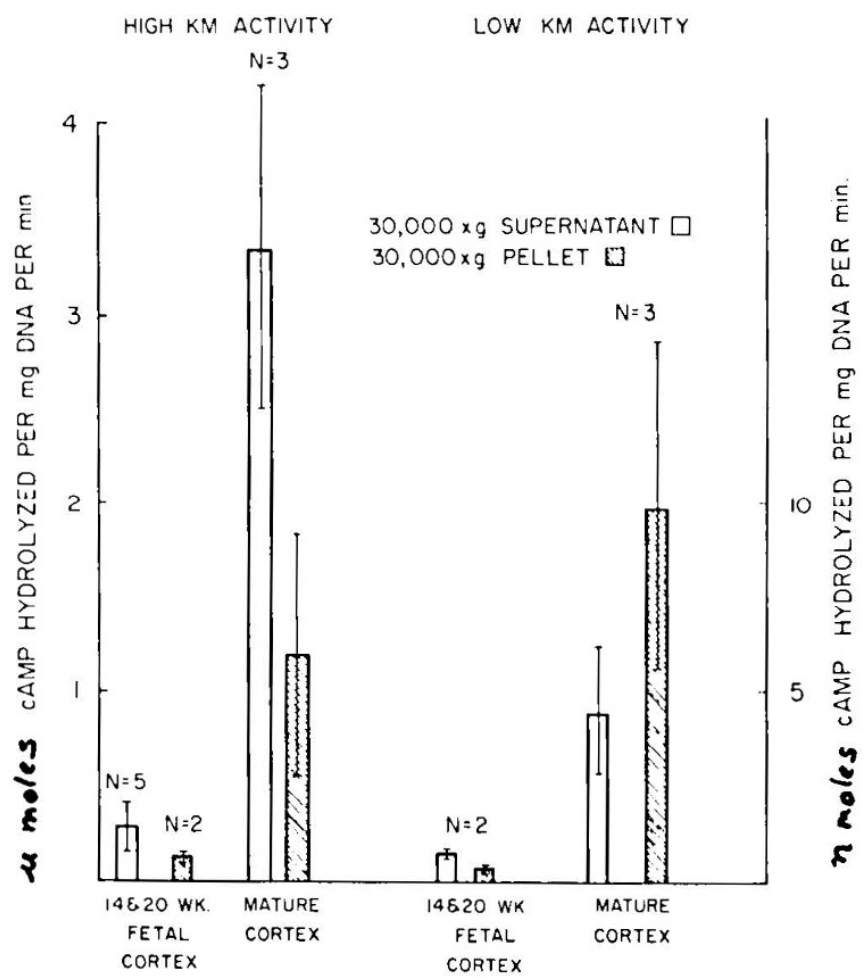

Fig. 1. Distribution of cyclic AMP (cAMP) phosphodiesterase activity in the fetal and mature human cerebral cortex. Frontal cortex containing both white and gray matter was homogenized in 3 volumes of glassdistilled water, freeze-thawed three times, spun at $30,000 \times g\left(0-4^{\circ}\right)$ for $30 \mathrm{~min}$, and dialyzed overnight in $20 \mathrm{mM}$ Tris buffer, ph 7.5 , at $4^{\circ}$. Fifty to $100 \mu \mathrm{g}$ protein were used; total volume $100 \mu \mathrm{l} ; \mathrm{Mn}^{++} 0.1 \mathrm{mM}$ in 40 mM Tris buffer, pH 7.4, incubated $34-36^{\circ}$ for 10 min. Reaction terminated by boiling for 3 min before product, $5^{\prime}$-AMP, was hydrolyzed with snake venom (Crotalus atrox). Substrate concentrations, $2 \mathrm{mM}$ and 2 $\mu \mathrm{N}$.

Table 3. Distribution of cyclic AMP activities in supernatant and particulate fractions of human cerebral cortex

Cyclic AMP phosphosphodiesterase

\begin{tabular}{|c|c|c|c|c|}
\hline \multirow{2}{*}{$\begin{array}{c}\text { Fraction } \\
\text { from subject } \\
\text { no. }\end{array}$} & \multicolumn{2}{|c|}{ High $\mathrm{K}_{\mathrm{m}}$ activity $(2 \mathrm{mM})^{\prime}$} & \multicolumn{2}{|c|}{ Low $\mathrm{K}_{\mathrm{m}}$ activity $(2 \mu \mathrm{M})^{\prime}$} \\
\hline & $\begin{array}{c}\mu \mathrm{mol} / \mathrm{g} \text { tis- } \\
\mathrm{suc} / \mathrm{min}\end{array}$ & $\begin{array}{l}\mu \mathrm{mol} / \mathrm{mg} \\
\mathrm{DNA} / \mathrm{min}\end{array}$ & $\begin{array}{l}\text { nmol/g tis- } \\
\text { sue/min }\end{array}$ & $\begin{array}{l}\mathrm{nmol} / \mathrm{mg} \\
\mathrm{DNA} / \mathrm{min}\end{array}$ \\
\hline \multicolumn{5}{|l|}{ Supernatant } \\
\hline 1 & 1.00 & 0.29 & & \\
\hline 2 & 1.02 & 0.42 & & \\
\hline 3 & 0.84 & 0.35 & 1.70 & 0.70 \\
\hline 4 & 0.41 & 0.24 & & \\
\hline 5 & 0.49 & 0.15 & 2.20 & $(0.88$ \\
\hline 6 & 0.52 & 1.73 & 0.96 & 3.20 \\
\hline 7 & 1.00 & 2.76 & 1.43 & 3.98 \\
\hline 8 & 1.26 & 5.61 & 1.42 & 6.29 \\
\hline \multicolumn{5}{|l|}{ Particulate } \\
\hline 3 & 0.05 & 0.13 & 0.82 & 0.34 \\
\hline 5 & 0.08 & 0.14 & 0.82 & 0.33 \\
\hline 6 & ().18 & 0.59 & 3.07 & 10.23 \\
\hline 7 & 0.41 & 1.13 & 1.92 & 5.32 \\
\hline 8 & 0.41 & 1.84 & 3.16 & 14.04 \\
\hline
\end{tabular}

' Substrate concentration.

for determination of the Michaclis constants. Two kinetic forms were assumed, one exhibiting a low $\mathrm{K}_{\mathrm{m}}$ or higher affinity and the other a high $\mathrm{K}_{\mathrm{m}}$ or lower affinity for each substrate. (See Figure 3 for representative Lineweaver-Burk plot.) Values obtained for half-maximum saturation and maximal velocities are presented 
Table 4. Distribution of cyclic GMP activities in supernatant and particulate fractions of human cerebral cortex

\begin{tabular}{|c|c|c|c|c|}
\hline \multirow{3}{*}{$\begin{array}{c}\text { Fraction } \\
\text { from } \\
\text { subject no. }\end{array}$} & \multicolumn{4}{|c|}{ Cyclic GMP phosphodiesterase } \\
\hline & \multicolumn{2}{|c|}{$\begin{array}{l}\text { High } \mathrm{K}_{m} \text { activity } \\
\quad(200 \mu \mathrm{M})^{1}\end{array}$} & \multicolumn{2}{|c|}{$\begin{array}{l}\text { Low } \mathrm{K}_{\mathrm{m}} \text { activity } \\
\qquad(2 \mu \mathrm{M})^{1}\end{array}$} \\
\hline & $\begin{array}{c}\mu \mathrm{mol} / \mathrm{g} \\
\text { tissue/min }\end{array}$ & $\begin{array}{c}\mu \mathrm{mol} / \mathrm{mg} \\
\mathrm{DNA} / \mathrm{min}\end{array}$ & $\begin{array}{c}\mathrm{nmol} / \mathrm{g} \\
\text { tissue/min }\end{array}$ & $\begin{array}{l}\mathrm{nmol} / \mathrm{mg} \\
\mathrm{DNA} / \mathrm{min}\end{array}$ \\
\hline \multicolumn{5}{|l|}{ Supernatant } \\
\hline 3 & 0.074 & 0.031 & 4.1 & 1.7 \\
\hline 5 & 0.083 & 0.025 & 4.2 & 1.2 \\
\hline 6 & 0.054 & 0.178 & 2.7 & 8.9 \\
\hline 7 & 0.113 & 0.312 & 2.7 & 7.4 \\
\hline 8 & 0.150 & 0.665 & 3.9 & 17.1 \\
\hline \multicolumn{5}{|l|}{ Particulate } \\
\hline 3 & 0.020 & 0.047 & 0.6 & 0.2 \\
\hline 5 & 0.042 & 0.075 & 1.5 & 0.6 \\
\hline 6 & 0.245 & 0.817 & 8.7 & 29.1 \\
\hline 7 & 0.118 & 0.327 & 4.0 & 11.2 \\
\hline 8 & 0.122 & 0.544 & 5.6 & 25.0 \\
\hline
\end{tabular}

${ }^{1}$ Substrate concentration.

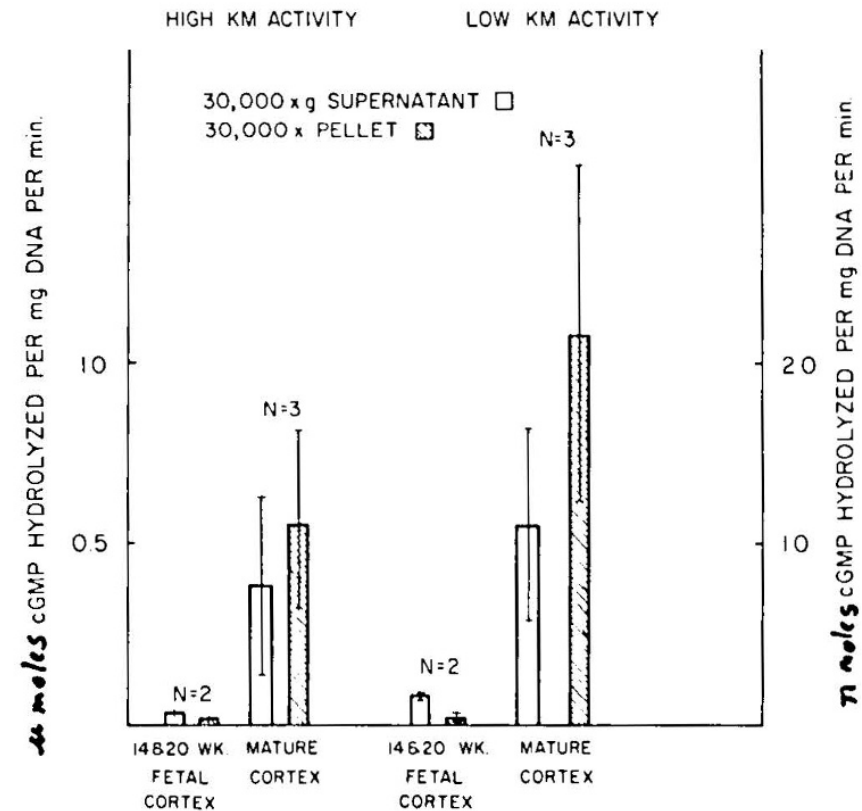

Fig. 2. Distribution of cyclic GMP ( $(G M P)$ phosphodiesterase activity in the fetal and mature human cerebral cortex. Incubation and assay conditions as for cyclic AMP phosphodiesterase using 25-50 $\mu \mathrm{g}$ protein. Substrate concentrations, $200 \mu \mathrm{M}$ and $2 \mu \mathrm{M}$.

in Table 5. Lower $K_{m}$ values were obtained for the high affinity cyclic GMP enzyme, a pattern seen in several tissues and species as reported by others (3). For the low affinity enzymes, the halfsaturation values were higher for cyclic GMP than for cyclic AMP by a factor of 2-3. In particulate fractions at higher substrate concentrations, these enzymes exhibit slightly greater affinity for cyclic AMP but with maximum hydrolysis of cyclic AMP at a rate substantially lower than for cyclic GMP. No significant differences were noted between fetal and mature cortices.

\section{EFFECT OF CYCLIC GMP ON CYCLIC AMP PHIOSPHODIESTERASE ACTIVITY}

Since phosphodiesterase activity is reported to be variably affected by the additional presence of the other cyclic nucleotide

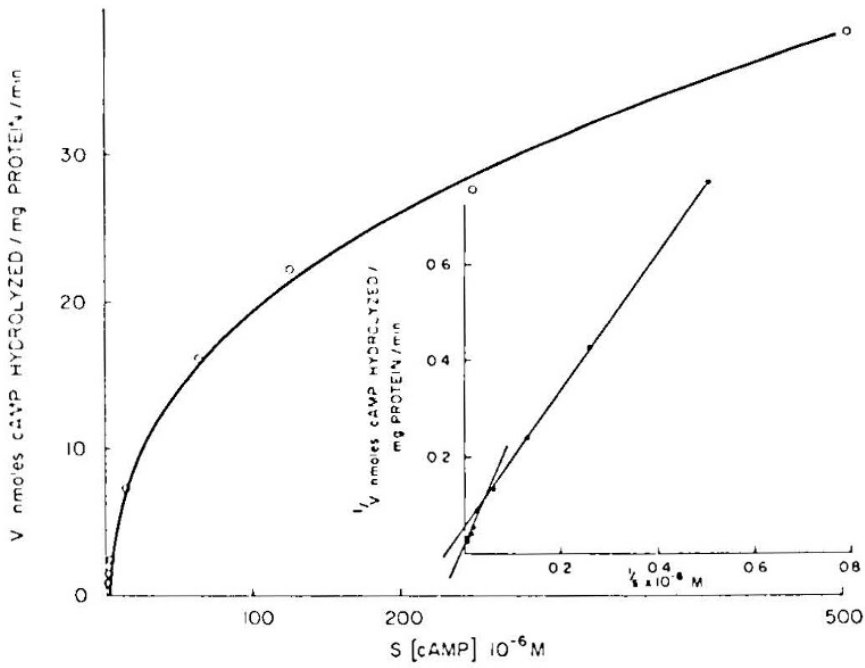

Fig. 3. Lineweaver-Burk plot of cyclic AMP (cAMP) hydrolysis by the $30,000 \times g$ supernatant fraction of a homogenized and freezethawed specimen of human cerebral cortex.

(4), the effect of one nucleotide on the hydrolysis of the other was examined.

In the mature cortex, the hydrolysis of $10^{-7} \mathrm{M}$ cyclic AMP was stimulated by the addition of cyclic GMP over the concentration range of $10^{-7}-10^{-5} \mathrm{M}$ as depicted in Figure 4 . Increasing the concentration of the added nucleotide resulted in a progressive reduction of stimulation. When cyclic GMP concentrations were increased to $10^{-4} \mathrm{M}$, hydrolysis of cyclic AMP was inhibited $85-$ $90 \%$.

The hydrolysis of higher concentrations of cyclic AMP $\left(10^{-5}\right.$ $10^{-4} \mathrm{M}$ ) was progressively inhibited competitively with increasing amounts of cyclic GMP.

\section{EFFECT OF CYCLIC AMP ON CYCLIC GMP PHOSPHODIESTERASE ACTIVITY}

The addition of $10^{-9}-10^{-7} \mathrm{M}$ cyclic AMP inhibited the hydrolysis of $2 \times 10^{-4} \mathrm{M}$ cyclic GMP in the fetus and adult. The fetus exhibits greater sensitivity to inhibition. When the added nucleotide is increased from $10^{-6}$ to $10^{-4} \mathrm{M}$, relief of inhibition was seen in the adult cortex (Fig. 5). Even at lower substrate concentrations, the addition of $10^{-9}-10^{-7} \mathrm{M}$ cyclic AMP also inhibited hydrolysis of cyclic GMP in the fetus. The mature brain, in contrast, was slightly stimulated under the same conditions. When the inhibitor concentrations were raised to $10^{-6}$ to $10^{-4}$ $M$, the brain of the fetus exhibited progressive release from inhibition (Fig. 6).

Since $N^{6}, 2^{\prime}$-O $O$-dibutyryl (db)-cyclic AMP has been observed to mimic some of the effects of cyclic AMP and is believed not to be hydrolyzed by PDE (36), the effect of varying concentrations of this analog on cyclic GMP hydrolysis was examined in the mature cortex.

A stimulatory effect was observed on cyclic GMP hydrolysis at high concentrations by $10^{-9} \mathrm{M}$ db-cyclic AMP which was sustained over increasing concentrations of the dibutyryl compound to $10^{-4} \mathrm{M}$. At low concentrations of cyclic GMP, $10^{-9} \mathrm{M}$ dbcyclic AMP inhibited the hydrolysis of the guanosine nucleotide; this inhibition was also sustained over increasing amounts of the added db-cyclic AMP (Fig. 7). These findings are suggestive that db-cyclic AMP may be an allosteric effector of the cyclic GMP phosphodiesterases which is permissive and stimulatory for the low affinity enzyme and inhibitory for the high affinity enzyme.

These results indicate that the hydrolysis of each cyclic nucleotide is variously affected by the presence of different concentrations of the other nucleotide and significant differences occur as a result of maturation. These findings may represent differences in the apoproteins, or they may represent the sum effect of a 
PHOSPHODIESTERASE IN CEREBRAL CORTEX

Table 5. Michaelis constants of cerebral cortical phosphodiesterases (PDE's)

\begin{tabular}{|c|c|c|c|c|c|c|c|c|}
\hline \multirow{3}{*}{$\begin{array}{l}\text { Fraction from } \\
\text { subject no. }\end{array}$} & \multicolumn{4}{|c|}{ Cyclic AMP PDE } & \multicolumn{4}{|c|}{ Cyclic GMP PDE } \\
\hline & \multicolumn{2}{|c|}{ High $\mathrm{K}_{\mathrm{m}}$ enzyme } & \multicolumn{2}{|c|}{ Low $K_{m}$ enzyme } & \multicolumn{2}{|c|}{ High $\mathrm{K}_{\mathrm{m}}$ enzyme } & \multicolumn{2}{|c|}{ Low $\mathrm{K}_{\mathrm{m}}$ enzyme } \\
\hline & $\mathrm{K}_{\mathrm{m}}{ }^{\prime}\left(\times 10^{-4}\right)$ & $V_{\max }^{2}$ & $K_{m}^{1}\left(\times 10^{-5}\right)$ & $V_{\max ^{2}}$ & $\mathrm{~K}_{\mathrm{m}}{ }^{1}\left(\times 10^{-4}\right)$ & $V_{\text {max }}^{2}$ & $\mathrm{~K}_{m^{1}}^{1}\left(\times 10^{-6}\right)$ & $V_{\text {max }}^{2}$ \\
\hline \multicolumn{9}{|l|}{ Supernatant } \\
\hline 1 & 0.77 & 52.6 & 0.77 & 6.7 & 2.22 & 54.1 & 5.0 & 6.67 \\
\hline 5 & 0.59 & 34.5 & 1.0 & 20.0 & 3.85 & 68.9 & 4.0 & 3.33 \\
\hline 6 & 1.06 & 66.7 & 2.0 & 6.7 & 2.54 & 71.4 & 10.0 & 10.00 \\
\hline 7 & 1.11 & 76.9 & 2.0 & 10.0 & 1.37 & 62.5 & 5.0 & 7.14 \\
\hline 8 & 1.43 & 125 & 2.0 & 10.0 & 1.67 & 76.9 & 5.0 & 10.00 \\
\hline \multicolumn{9}{|l|}{ Particulate } \\
\hline 1 & 2.86 & 1.70 & 1.25 & 0.10 & & & 5.0 & 0.67 \\
\hline 5 & 1.25 & 1.25 & 0.67 & 0.20 & 6.67 & 10.0 & 1.0 & 0.50 \\
\hline 6 & 1.10 & 1.67 & 1.0 & 0.10 & 1.67 & 62.5 & & \\
\hline 7 & 0.77 & 1.43 & 1.67 & 0.20 & 6.67 & 100 & 3.57 & 1.67 \\
\hline 8 & 1.43 & 0.50 & 1.67 & 0.25 & & & 2.63 & 1.11 \\
\hline
\end{tabular}

1 Molar concentration.

${ }^{2}$ Nanomoles per ing per min.

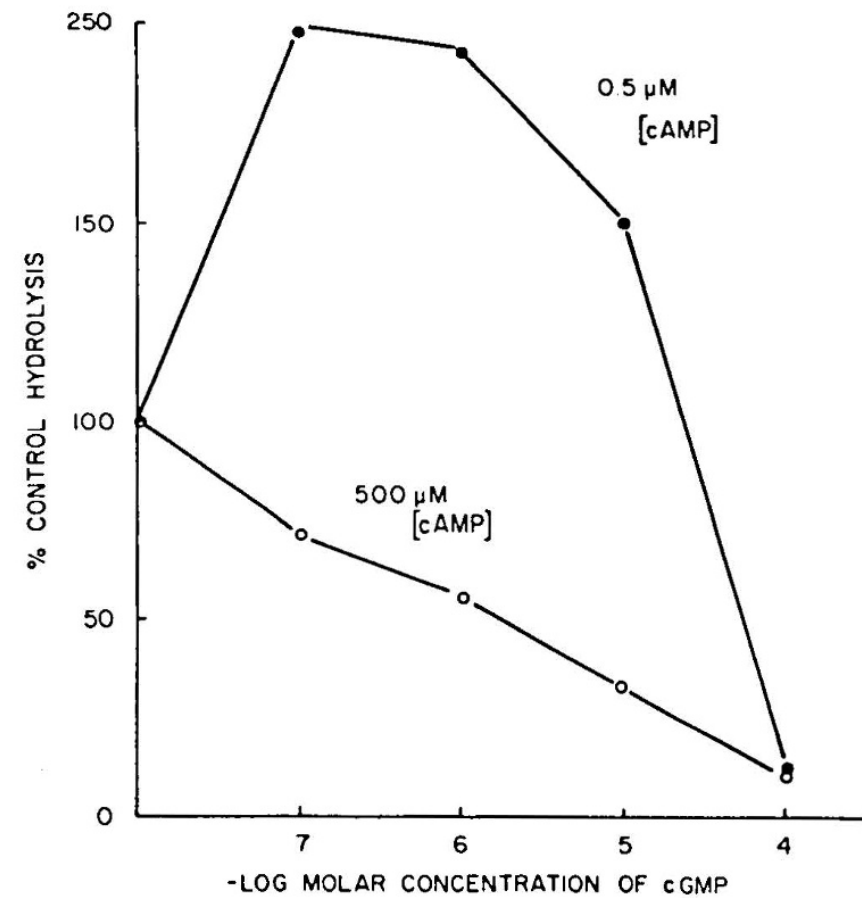

Fig. 4. Effect of cyclic GMP (cGMP) on cyclic AMP (cAMP) phosphodiesterase. Plotted as percentage of control or baseline hydrolysis. - - : cyclic AMP concentration $0.5 \mu \mathrm{M}$. ○- $\mathrm{O}$ : cyclic AMP concentration $500 \mu \mathrm{M}$. Supernatant fractions used. (Subject 8: initial activity with $500 \mu \mathrm{M}$ cyclic AMP was $38.9 \mathrm{nmol} / \mathrm{mg}$ protein/min and with $0.5 \mu \mathrm{M}$ cyclic AMP activity was $181 \mathrm{pmol} / \mathrm{mg}$ protein $/ \mathrm{min}$ ).

variety of factors as, for instance, in the binding proteins and protein kinases which are also undergoing developmental change. In the absence of differences of the Michaelis constants or further purification of the enzymes, the basis of the observed findings is not apparent. However, variability of the effect of one nucleotide on the hydrolysis of the other does not reflect concordance, suggesting that simple competitive inhibition may be but one of several mechanisms by which one cyclic nucleotide affects the hydrolysis of the other.

\section{EFFECTS OF A NONIONIC DETERGENT, TRITON X-100}

In the rat, homogenates of brain reportedly exhibit a latent phosphodiesterase activity which could be unmasked by the use

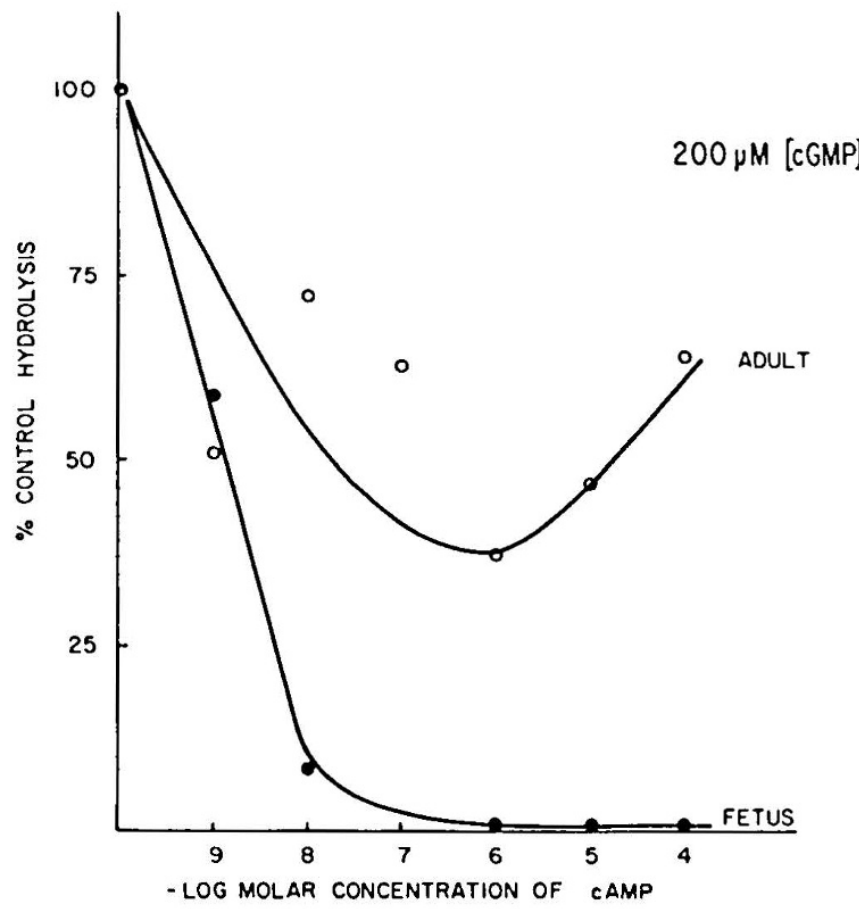

Fig. 5. Effect of cyclic AMP (cAMP) on cyclic GMP ( $C G M P$ ) phosphodiesterase. Values were plotted as percentage of control or baseline hydrolysis which were as follows: subject $2,37.03 \mathrm{nmol} / \mathrm{mg}$ protein $/ \mathrm{min}$ and subject $8,34.53 \mathrm{nmol} / \mathrm{mg}$ protein $/ \mathrm{min}$. - : supernatant fractions of the fetus (subject 2) when cyclic GMP concentration was 200 $\mu \mathrm{M} ; \mathrm{O}-\mathrm{O}$ : supernatant fractions of the mature cortex (subject 8) with $200 \mu \mathrm{M}$ cyclic GMP.

of nonionic detergents (10). The effect of $0.2 \%$ Triton X-100 (v/ v) on the two kinetic forms of the cyclic AMP and cyclic GMP PDE of the human cerebral cortex was, therefore, examined. In the mature cortex, over a range of $5 \times 10^{-8}-10^{-4} \mathrm{M}$ cyclic AMP concentration, Triton X-100 had a slightly inhibitory effect on cyclic AMP hydrolysis, which decreased the $\mathrm{V}_{\max }$ by $55 \%$ at high substrate concentrations and the affinity (increased in $K_{m}$ by 2 fold) over low substrate concentrations.

Over comparable concentration ranges of cyclic GMP, inhibition due to Triton X-100 was again seen and was due to reduction of the maximal velocities in both the mature and immature brains and in the several fractions examined. 


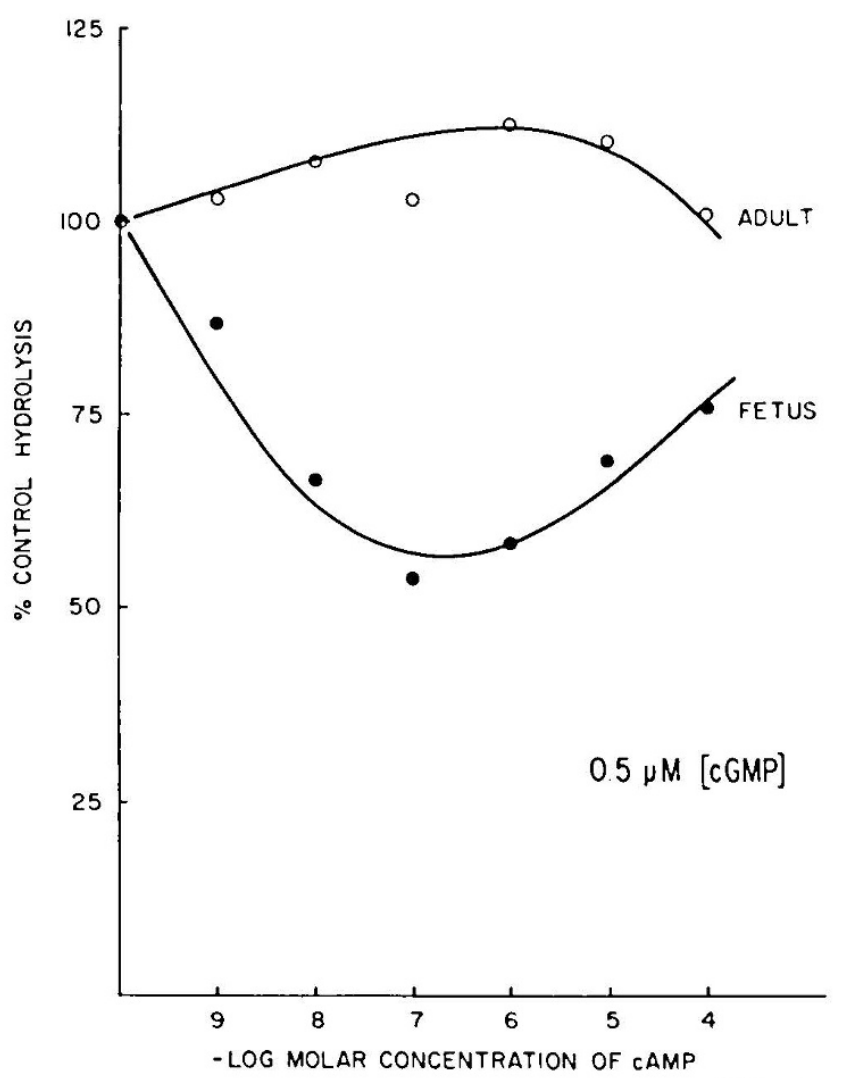

Fig. 6. Lffect of cyclic AMP (CAMP) on cyclic GiMP ( $(F M P)$ phosphodiesterase. Values were plotted as pereentage of control or baseline hydrolysis and were $495 \mathrm{pmol} / \mathrm{mg}$ protein/min for the mature cortex (subject 8 ) and $336 \mathrm{pmol} / \mathrm{mg}$ protein/min for the fetal cortex (subject 2 ). Supernatant fractions of the fetus $(\bullet-\bullet)$ and of the mature cortex $(\mathrm{O}-\mathrm{O})$. Cyclic GMP, $0.5 \mu \mathrm{M}$.

These results suggest that latency of PDE activity is not encountered in the preparations used in our study. Differences between our results and the animal study may represent species differences, although llardman (16) observed an inhibitory effect of $0.01 \%$ Triton X-100 on the activity of the cyclic AMP PDE in the rat liver which was as much as $50 \%$ inhibited at high substrate concentrations.

\section{EFFECT OF THEOPHYLLINE}

Variability of drug effects has been demonstrated for the PDE's of the two cyclic nucleotides and is exemplified by the greater selectivity of theophylline for cyclic $A M P$ rather than cyclic GMP PDE in the lung of the guinea pig (2). In the human cerebral cortex, a similar selectivity for the cyclic $\triangle M P$ PDE is seen. At $1 \mathrm{mM}$ substrate concentration, cyclic AMP hydrolysis is markedly inhibited, whereas cyclic GMP hydrolysis is relatively unaffected by millimolar amounts of theophylline (see IFig. 8) in either the mature or immature cortex. At micromolar concentrations of substrate, the hydrolysis of both nucleotides was inhibited to a degree comparable to that observed for cyclic AMP at $1 \mathrm{mM}$. At all substrate concentrations studied, the fetal cortex was slightly more sensitive to the inhibitory effects of theophylline than the mature cortex.

Although the in vivo effects of theophylline are not limited to PDE inhibition alone and theophylline concentrations of 1 to 8 $\mathrm{mM}$ are rarely achieved clinically, the difference exhibited by the low affinity enzymes indicate that tissue concentrations of the two cyclic nucleotides would vary considerably in the presence of theophylline.

\section{EFIEC'T OF IMIDAZOLE:}

Imidazole has been demonstrated to stimulate the high $\mathrm{K}_{m}$ PDE of the brain preparations of a number of species (12), although no effect is observed on the low $K_{m}$ PDIE for a number of them (1).

In both fetal and mature brains, concentrations of imidazole of 20 and $40 \mathrm{mM}$ had a stimulatory effect of $25-50 \%$ on cyclic AMP and cyclic GMP hydrolysis at high substrate concentrations, whereas an inhibitory effect of $2.5 \%$ was seen at micromolar concentrations of cyclic GMP. Although a mild inhibitory effect was observed at micromolar concentrations of cyclic AMP in mature brains, a $20 \%$ stimulation of activity was observed in fetal brains in the presence of $40 \mathrm{mM}$ imidazole.

\section{EFFECT OF BOVINE ACTIVATOR PROTLIN}

Activation of brain PDE activity by a heat-stable, nondialyzatble factor present in brain extracts has been ascribed to a calcium binding protein by a number of workers $(14,21,22,42)$. The possible regulatory role played by this factor is not clear since it is ubiquitous (37), is usually present in excess even in tissues where PDE activity is barely detectable (37), appears to activate only one of the several forms of PDIE obtained by physical separation methods (48), and appears to stimulate adenylate cyclase activity as well (6).

The addition of $10 \mu \mathrm{g}$ bovine activator protein, which has been shown to stimulate the PDE's of other species, had no significant effect on the tissues examined. This could indicate that saturating amounts of the endogenous activator were present in the samples or that the preparation of bovine activator used did not activate the human enzyme (see Table 6).

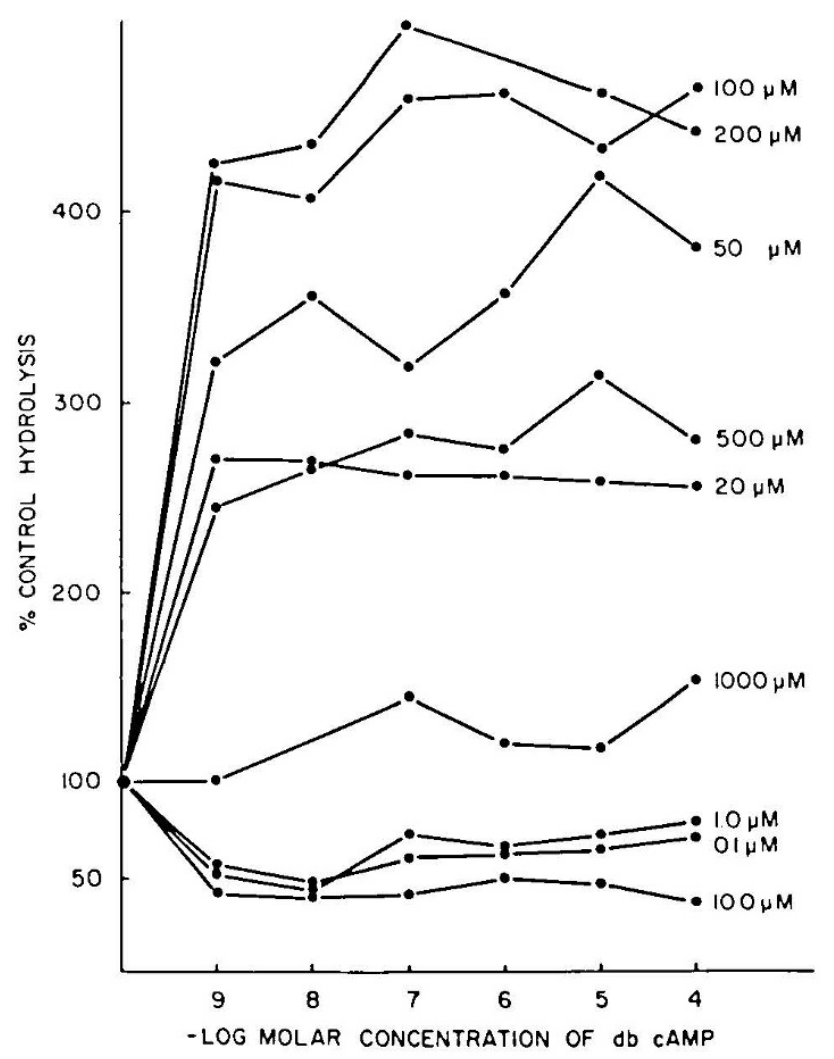

Fig. 7. Effect of dibutyryl-cyclic AMP (db CA.MP) on cyclic GMPP hydrolysis. Plotted as percentage of control or baseline hydrolysis at varying substrate concentrations of cyclic GMP. 0.1 to $1,000 \mu \mu \mathrm{M}$. Supernatant of mature cortex used. 


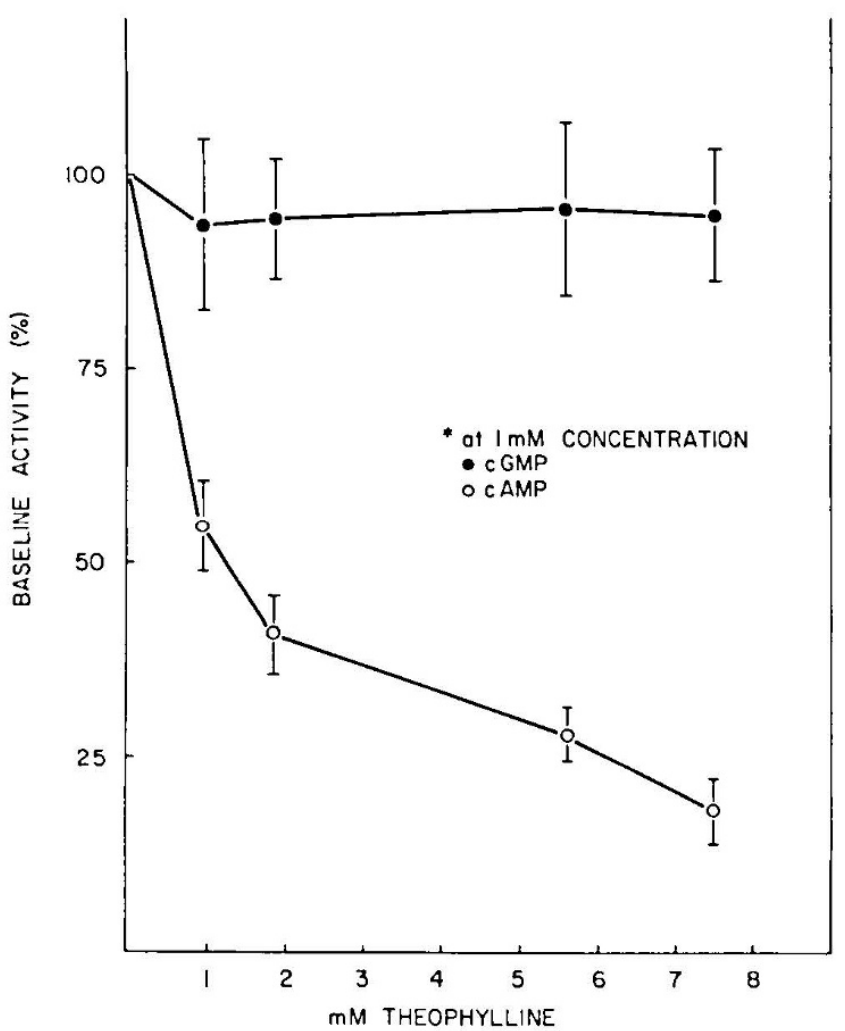

Fig. 8. Effect of theophylline on cyclic nucleotide hydrolysis in the human cerebral cortex. Plotted as pereentage of control or baseline hydrolysis at $1 \mathrm{mM}$ cyclic AMP (cAMP) concentrations $(\mathrm{O}-\mathrm{O})$ and 1 mM cyclic GMP (cGMP) concentrations $(\bullet-\bullet)$ using the supernatant fractions.

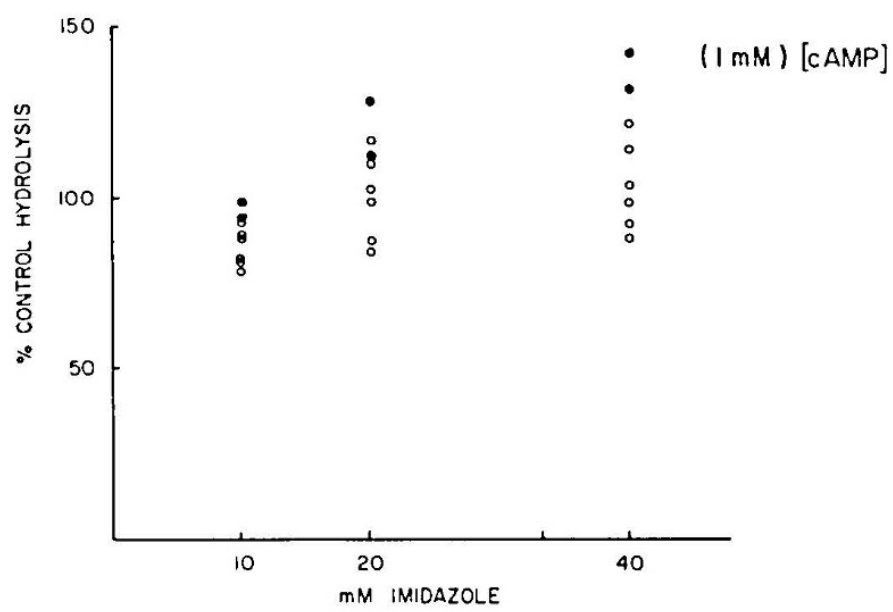

Fig. 9. Effect of imidazole on cyclic AMP ( $A M M P$ ) phosphodiesterase activity. Plotted as percentage of control or baseline hydrolysis of the supernatant fractions of eight separate subjects $(O$ : mature subjects, fetuses).

\section{DISCUSSION}

When total phosphodiesterase activity is compared on a DNA basis, measurable but low activities are found in the fetus whereas high activities are found in the cortex from young adults. At high substrate concentrations, both mature and immature brains hydrolyze cyclic AMP more readily than cyclic GMP and at low substrate concentrations this preference is reversed.

In the fetus, more activity for both nucleotides at high and low concentrations is associated with the supernatant fraction. With
Table 6. Effect of bovine activator protein on phosphodiesterase activities of human cerebral cortex

$\%$ of control hydrolysis at various substrate concentrations

\begin{tabular}{lccccc}
\cline { 2 - 3 } & \multicolumn{2}{c}{ Cyclic AMP } & & \multicolumn{2}{c}{ Cyclic GMP } \\
\cline { 2 - 3 } \cline { 5 - 6 } Parameter & $1 \mathrm{mM}$ & $2 \mu \mathrm{M}$ & & $500 \mu \mathrm{M}$ & $2 \mu \mathrm{M}$ \\
\hline Mean (\%) & 79.3 & 104 & & 113 & 103 \\
Range (\%) & $61.3-92.5$ & $82.9-124.6$ & & $63.5-216$ & $90.7-116$ \\
SD (\%) & \pm 9.4 & \pm 13.6 & & \pm 49.1 & \pm 8.0 \\
No. of & 8 & 8 & & 8 & 7 \\
$\quad$ subjects & & & & & \\
\hline
\end{tabular}

maturity, there is a shift in localization of high $\mathrm{K}_{m}$ activity for cyclic GMP and low $\mathrm{K}_{\mathrm{m}}$ activities for both nucleotides to the particulate fraction.

These findings differ in several respects from reports of animal studies. Beavo et al. (4) found that whereas the hydrolysis of cyclic GMP and cyclic AMP by homogenate and subcellular fractions from bovine heart and several rat tissues was nearly the same at millimolar levels of substrate, at $\mu \mathrm{M}$ concentrations, cyclic GMP was hydrolyzed more efficiently than cyclic AMP in most fractions studied. This activity was attributed by them to a low $\mathrm{K}_{\mathrm{m}}$ PDE exhibiting a higher affinity for the guanosine than the adenosine nucleotide. Kakiuchi et al. (22) found the supernatant fractions of a variety of rat tissues to contain much more activity for the hydrolysis of cyclic GMP than for cyclic AMP, which led these authors to suggest that the function of the $\mathrm{Ca}^{++}$and $\mathrm{Mg}^{++}$-dependent cyclic nucleotide PDE was probably to hydrolyze cyclic GMP preferentially.

Localization of the majority of the low $\mathrm{K}_{\mathrm{m}}$ activity with the particulate fraction of preparations has been reported for many mammalian tissues (43). The low $\mathrm{K}_{\mathrm{m}}$ PDE is believed to play a more significant role in regulating the basal, intracellular concentration of the cyclic nucleotides since the half-maximal concentration of substrate for maximum velocity is at physiologic tissue levels of the nucleotides.

In the mature cortex, localization of the bulk of the low $\mathrm{K}_{\mathrm{m}}$ activity for cyclic AMP hydrolysis in the particulate fraction might offer an advantage for regulating the intracellular concentration of cyclic AMP since it has been established that the enzyme of synthesis, adenylate cyclase, is membrane bound (41). Such an advantage may not exist for the low $K_{m}$ cyclic GMP PDE since guanylate cyclase appears to be soluble in most of the tissues studied (18). It has been suggested, however, that the solubility of guanylate cyclase may be a dissociative artifact of the processing of tissues (17) and that guanylate cyclase is also membrane bound. In the latter case, the proxinity of the synthetic and degradative enzymes for cyclic GMP would allow for the close monitoring of the intracellular level of the cyclic nucleotide expected of a highly regulated system.

The influence of one cyclic nucleotide on the hydrolysis of the other was variable in the fetal and mature cortex. A diminution of inhibition at high concentrations of added nucleotide was seen in the adult cortex for cyclic GMP PDE. The addition of millimolar amounts of unlabeled cyclic AMP or GMP to the reactants of our PDE assays after boiling and before the addition of the snake venom followed by the addition of resin according to the method of Thompson and Appleman (44) did not increase the amount of recoverable label in the supernatant. Thus, a technical artifact could not be found to explain this observation.

Highly variable effects on the hydrolysis of the nucleotides have been reported for a number of different tissues by the addition of the other nucleotide. Beavo et al. (4) reported that in bovine heart and rat liver the presence of $10^{-6}-10^{-5} \mathrm{M}$ concentrations of either nucleotide was inhibitory to the hydrolysis of 
$10^{-6} \mathrm{M}$ concentrations of the other nucleotide. At low concentrations of cyclic GMP $\left(10^{-7} \mathrm{M}\right)$, the hydrolysis of cyclic AMP was stimulated 2 -fold in rat liver but not in bovine heart (4). In a follow-up study on other tissues of the rat, a stimulatory effect of $10^{-8} \mathrm{M}$ concentration of cyclic GMP was seen on particulate preparations of the liver, brain, kidney, heart, and thymus and on soluble preparations of the liver and thymus. Increasing the concentration of cyclic GMP to $10^{-5} \mathrm{M}$, on the other hand, was inhibitory (5).

In a rat brain preparation, O'Dea et al. (28) observed that although $10^{-7}$ to $10^{-6} \mathrm{M}$ cyclic GMP was competitively inhibited by $10^{-6}$ to $10^{-5} \mathrm{M}$ cyclic AMP, the hydrolyses of cyclic AMP was unaffected by comparable amounts of cyclic GMP. Similar findings were reported by Rosen (31) for the frog erythrocyte at millimolar concentrations of substrate and inhibitor.

At more physiologic concentrations of substrate and inhibitor, Sakai et al. (34) observed in the fat cells of the Wistar rat that the hydrolysis of low concentrations of either cyclic nucleotide was stimulated by the presence of $10^{-8}-10^{-7} \mathrm{M}$ concentrations of the other. Higher concentrations of the added nucleotide, $10^{-5} \mathrm{M}$, were inhibitory by a noncompetitive mechanism for cyclic AMP hydrolysis and competitively for cyclic GMP hydrolysis (34).

The physiologic significance of our findings is not readily apparent, particularly with respect to the high concentrations of substrate and "inhibitor" interrelationships. If a simplistic view is taken that two levels for each cyclic nucleotide may be critical in tissues, the following interpretation may be made. At the concentration of each nucleotide in tissues, a stimulatory influence is exerted on each PDE to ensure the maintenance of low, basal concentrations of each nucleotide. In the mature cortex, the stimulatory effect of cyclic GMP on cyclic AMP hydrolysis is greater than the influence of cyclic $A M P^{P}$ on cyclic GMP degratdation. Since cortical cells tend to degrade more cyclic GMP than AMP at low substrate concentrations, this is suggestive that the net effect of rather comparable tissue levels may result for both nucleotides, assuming that rates of synthesis of each are similar. However, the apparent greater affinity of these enzymes for cyclic GMP at low concentrations (see Table 5) indicates that tissue cyclic GMP levels would be lower than cyclic AMP if rates of synthesis of the two cyclic nucleotides are indeed similar. When adenylate or guanylate cyclase is maximally stimulated, the presence of basal amounts of the other nucleotide serves to raise the tissue concentration of the nucleotide being synthesized even further, allowing a critical level to be reached more quickly for the activation of specific kinases. Under such maximal stimulation, the presence of the other nucleotide in high concentrations results in a difference of effect on the specific PDE responsible for the hydrolysis of the newly synthesized nucleotide. When adenylate cyclase is stimulated, high levels of cyclic AMP are reached in the presence of high levels of cyclic GMP. If guanylate cyclase is stimulated, cyclic GMP levels reached are comparable to that observed in the absence of added cyclic AMP despite the presence of $10^{-5}$ and $10^{-4} \mathrm{M}$ cyclic AMP. If the two cyclases can be comparably stimulated in the adult cerebral cortex, these findings indicate that higher levels of cyclic GMP may not be favored by at least one of the factors regulating the concentrations of the cyclic nucleotides in the brain. In the fetus, on the other hand, these interrelationships appear to favor the sparing of cyclic GMP from degradation.

Since db-cyclic AMP, which is probably not actively metabolized by the phosphodiesterases, inhibits the hydrolysis of cyclic GMP catalyzed by enzyme with low $\mathrm{K}_{\mathrm{m}}$ and stimulates the high $\mathrm{K}_{\mathrm{m}}$ enzyme, it is possible that one nucleotide exerts an allosteric effect on the hydrolysis of the other at low and high substrate concentrations.

Evidence of the separateness of the several forms of PDE has been reported by Russell et al. (33), Kakiuchi $e t$ al. (22), and others on the basis of kinetic analysis of physically separated proteins; the fact that these enzymes are under separate control was reported by Pastan's group (32). The effects of theophylline on cyclic nucleotide hydrolysis are attributed to inhibition of
PDE (40), and correlations between theophylline concentration and physiologic responsiveness have been shown (8). Our observation of differences in sensitivity of the cyclic GMP PDE's to theophylline suggests that the active sites for each of the GMP enzymes may be separate. Further, the variability of the effect of theophylline on the guanosine and adenosine PDE's at high substrate concentrations also tends to support the concept that these sites may be different.

\section{CONCLUSION}

Since cyclic AMP has been shown to play a significant role in the differentiation of developing tissues and hormone production, and responsiveness may be present in a number of tissues from early stages in man (27), characterization of the enzymes which regulate the levels of the cyclic nucleotides in the cerebral cortex of man at various ages may be of importance because the putative neurotransmitters utilize these nucleotides to effect their neuroendocrine functions. The data reported here, although limited to the immature and mature cortex, indicate that total enzyme activity and distribution of PDE in the cerebral cortex of man are age dependent. In addition, differences in response to stimulators and inhibitors can be found at both extremes of maturation. This was most notable with respect to the influence of one nucleotide on the hydrolysis of the other. In the absence of differences of the kinetic constants, these findings may be the result of other factors which are undergoing changes simultaneously but which are not directly part of the apoprotein of the PDE's. Further purification of the enzymes will be necessary to explore the possibility of isozymes. Whether these differences are due to maturation of neuroblasts, glial proliferation, or to both processes cannot be determined from our studies. Finally, differences noted at low and high substrate concentrations in the presence of the other nucleotide at both extremes of maturity together with differences in responsiveness to theophylline confirm the notion that the active sites for the hydrolysis of the guanosine and adenosine nucleotides may be separate.

\section{REFERENCES AND NOTES}

1. Allen, D. O., and Clark, J. B.: Effect of various antilipolytic compounds on adenyl cyclase and phosphodiesterase activity in isolated fat cells. Advan. Enzyme Regul., 9: 99 (1971).

2. Amer, M. S., and Kreighbaum, W. E.: Cyclic nucleotide phosphodiesterases: properties, activators, inhibitors: Structural-activity relationships and possible role in drug development. J. Pharmaceut. Sci., 64: 1 (1975).

3. Appleman, M. M., Thompson, W. J., and Russell, T. R.: Cyclic nucleotide phosphodiesterases. Advan. Cyclic Nucl. Res., 3: 65 (1973).

4. Beavo, J. A., Hardman, J. G., and Sutherland, E. W.: Hydrolysis of cyclic guanosine and adenosine $3^{\prime}, 5^{\prime}$-monophosphates by rat and bovine tissues. J. Biol. Chem., 245: 5649 (1970).

5. Beavo, J. A., Hardman, J. G., and Sutherland, E. W.: Stimulation of adenosine $3^{\prime}, 5^{\prime}$-monophosphate hydrolysis by guanosine $3^{\prime}, 5^{\prime}$-monophosphate. J. Biol. Chem., 426: 3841 (1971).

6. Brostrom, C. O., Huang, Y. C., Breckenridge, B. M., and Wolff, D. J.: Identification of a calcium-binding protein as a calcium-dependent regulator of brain adenylate cyclase. Proc. Nat. Acad. Sci. U.S.A., 72: 64 (1975).

7. Burton, K.: Determination of DNA concentration with diphenylamine. Methods Enzymol., 12B: 163 (1968).

8. Butcher, R. W., and Sutherland, E. W.: Adenosine 3',5'-phosphate in biological materials. I. Purification and properties of cyclic $3^{\prime}, 5^{\prime}$-nucleotide phosphodiesterase and use of this enzyme to characterize adenosine $3^{\prime}, 5^{\prime}$ phosphate in human urine. J. Biol. Chem., 237: 1244 (1962).

9. Chader, G. J.: Hormonal effects on the neural retina: Induction of glutamine synthetase by cyclic 3',5'-AMP. Biochem. Biophys. Res. Commun., 43: $1102(1971)$

10. Cheung, W. Y., and Salganicoff, L.: Cyclic 3',5'-nucleotide phosphodiesterase: Localization and latent activity in rat brain. Nature, 214:90 (1967).

11. Dobbing, J., and Sands, J.: Timing of neuroblast multiplication in developing human brain. Nature, 226: 639 (1970).

12. Goldberg, N. D., Lust, W. D., O'Dea, R. F., Wei, S., and O'Toole, A. G.: A role of cyclic nucleotides in brain metabolism. Advan. Biochem. Psychopharmacol., 3: 67 (1970)

13. Goldberg, N. D., O'Dea, R. F., and Haddox, M. K.: Cyclic GMP. Advan. Cyclic Nuc. Res., 3: 155 (1973).

14. Goren, E. N., and Rosen, O. M.: The effect of nucleotides and a nondialyzable factor on the hydrolysis of cyclic AMP by a cyclic nucleotide phosphodiesterase from beef heart. Arch. Biochem. Biophys., 42: 720 (1971)

15. Greengard, P., McAfec, D. A., and Kebabian, J. W.: On the mechanism of 
action of cyclic AMP and its role in synaptic transmission. Advan. Cyclic Nucl. Res., 1: 337 (1972).

16. Hardman, J. G.: Stimulation of rat liver phosphodiesterase by cyclic GMP: Alteration by Triton, $\mathrm{Ca}^{++}$and EGTA. Advan. Cyclic Nucl. Res., 1: 574 (1972).

17. Hardman, J. G., Beavo, J. A., Gray, J. P., Chrisman, T. D., Patterson, W. D., and Sutherland, E. W.: The formation and metabolism of cyclic GMP. Ann. N. Y. Acad. Sci., 185: 27 (1971).

18. Hardman, J. G., and Sutherland, E. W.: Guanyl cyclase, an enzyme catalyzing the formation of guanosine $3^{\prime}, 5^{\prime}$-monophosphate from guanosine triphosphate. J. Biol. Chem., 244: 6363 (1969)

19. Himwich, W.: In: W. Himwich: Biochemical Development of the Brain, Vol. 1 (Dekker, Inc., New York, 1973).

20. Hoffer, B. J., Siggins, G. R., Oliver, A. P., and Bloom, F. E.: Cyclic AMP mediation of norepinephrine inhibition in rat cerebellar cortex: $A$ unique class of synaptic responses. Ann. N. Y. Acad. Sci., 185: 531 (1971).

21. Kakiuchi, S., and Yamazaki, R.: Calcium dependent phosphodiesterase activity and its activating factor (PAF) from brain: Studies on cyclic 3'.5' nucleotide phosphodiesterase (III). Biochem. Biophys. Res. Commun., 41: $1104(1970)$.

22. Kakiuchi, S., Yamazaki, R., Teshima, Y., Uenishi, K., and Miyamoto, E.: Multiple cyclic nucleotide phosphodiesterase activities from rat tissues and occurrence of a calcium-plus-magnesium-ion-dependent protein and its protein activator. Biochem. J., I46: 109 (1975)

23. Keen, P., and McLean, W. G.: Effect of dibutyryl cyclic AMP on levels of dopamine-b-hydroxylase in isolated superior cervical ganglia. Arch. Pharmacol., 275: 465 (1972).

24. Klein, D. C., Berg, G. R., and Weller, J.: Melatonin synthesis: Adenosine $3^{\prime}, 5^{\prime}$-monophosphate and norepinephrine stimulate $N$-acetyltransferase. Science, 168: 979 (1970).

25. Lowry, O. H., Rosebrough, N. J., Farr, A. L., and Randall, R. J.: Protein measurement with the Folin phenol reagent. J. Biol. Chem., 193: 257 (1951).

26. Mackay, A. V. P., and Iversen, L. L.: Increased tyrosine hydroxylase activity of sympathetic ganglia cultured in the presence of dibutyryl cyclic AMP. Brain Res., 48: 424 (1972).

27. Menon, K. M. J., Giese, S., and Jaffe, R. B.: Hormone- and fluoride-sensitive adenylate cyclases in human fetal tissues. Biochim. Biophys. Acta, 304: 203 (1973).

28. O'Dea, R. F., Haddox, M. K., and Goldberg, N. D.: Kinetic analysis of a soluble rat brain cyclic nucleotide phosphodiesterase. Fed. Proc., 29: 473 (1970).

29. Otten, J., Johnson, G. S., and Pastan, I.: Cyclic AMP levels in fibroblasts: Relationship to growth rate and contact inhibition of growth. Biochem. Biophys. Res. Commun., 44: 1192 (1971).

30. Prasad, K. N., and Vernadakis, A .: Morphological and biochemical study in xray and dibutyryl cyclic-AMP-induced differentiated neuroblastoma cells. Exp. Cell Res., 70: 27 (1972).

31. Rosen, O. M.: Interaction of cyclic GMP and cyclic AMP with a cyclic nucleotide phosphodiesterase of the frog erythrocyte. Arch. Biochem. Biophys., 139: 447 (1970).

32. Russell, T. R., and Pastan, I. H.: Cyclic adenosine $3^{\prime}, 5^{\prime}$-monophosphate and cyclic guanosine $3^{\prime}, 5^{\prime}$-monophosphate phosphodiesterase activities are under separate genetic control. J. Biol. Chem., 249: 7764 (1974).

33. Russell, T. R., Terasaki, W. L., and Appleman, M. M.: Separate phosphodiesterases for the hydrolysis of cyclic adenosine 3 ',5'-monophosphate and cyclic guanosine $3^{\prime}, 5^{\prime}$-monophosphate in rat liver. J. Biol. Chem., 248 1334 (1973).

Copyright (1) 1977 International Pediatric Research Foundation, Inc.
34. Sakai, T., Thompson, IV. J., Lavis, V. R., and Williams, R. H.: Cyclic nucleotide phosphodiesterase activities from isolated fat cells: Correlation of subcellular distribution with effects of nucleotides and insulin. Arch. Biochem. Biophys., 162: 331 (1974).

35. Schmidt, M. J. Palmer, E. C., Dettbarn, W. D., and Robison, G. A.: Cyclic AMP and adenyl cyclase in the developing rat brain. Dev. Psychobiol., 3: 53 (1970).

36. Simon, L. N., Shuman, D. A., and Robins, R. K.: The chemistry and biological properties of nucleotides related to nucleoside $3^{\prime}, 5^{\prime}$-cyclic phosphates. Advan. Cyclic Nucl. Res., 3: 225 (1973).

37. Smoake, J. A., Song, S. Y., and Cheung, IV. Y.: Cyclic $3^{\prime}, 5^{\prime}$-nucleotide phosphodiesterase distribution and developmental changes of the enzyme and its protein activator in mammalian tissues and cells. Biochim. Biophys. Acta, 341: 402 (1974).

38. Stone, T. W., Taylor, D. A., and Bloom, F. E.: Cyclic AMP and cyclic GMP may mediate opposite neuronal responses in the rat cerebral cortex. Science, 187: 845 (1975).

39. Strada, S. J., Uzunov, P., and Weiss, B.: Ontogenetic development of a phosphodiesterase activator and the multiple forms of cyclic AMP phosphodiesterase of rat brain. J. Neurochem., 23: 1097 (1974).

40. Sutherland, E. W., and Rall, T. R.: Fractionation and characterization of a cyclic adenine ribonucleotide formed by tissue particles. J. Biol. Chem. 232. 1077 (1958)

41. Sutherland, E. W., Rall, T. R., and Menon, T.: Adenyl cyclase. I. Distribution, preparation and properties. J. Biol. Chem., 237: 1220 (1962).

42. Teo, T.S., Wang, T. H., and Wang, J. H.: Purification and properties of the protein activator of bovine heart cyclic adenosine $3^{\prime}, 5^{\prime}$-monophosphate phosphodiesterase. J. Biol. Chem., 248: 588 (1973).

43. Thompson, W. J., and Appleman, M. M.: Characterization of cyclic nucleotide phosphodiesterases of rat tissues. J. Biol. Chem., 246: 3145 (1971)

44. Thompson, W. J., and Appleman, M. M.: Multiple cyclic nucleotide phosphodiesterase activities from rat brain. Biochemistry, 10: 311 (1971).

45. Waymire, J. C., Weiner, N. and Prasad, K. N.: Regulation of tyrosine hydroxylase activity in cultured mouse neuroblastoma cells: Elevation induced by analogs of adenosine $3^{\prime}, 5^{\prime}$-monophosphate. Proc. Nat. Acad. Sci U.S.A., 69: 2241 (1972).

46. Weiss, B.: Ontogenetic development of adenyl cyclase and phosphodiesterase in rat brain. J. Neurochem., 18: 469 (1971).

47. Weiss, B., and Costa, E.: Regiona! and subcellular distribution of adenyl cyclase and $3^{\prime}, 5^{\prime}$-cyclic nucleotide phosphodiesterase in brain and pineal gland. Biochem. Pharmacol., 17: 2107 (1968).

48. Weiss, B., Fertel, R., Figlin, R., and Uzunov, P.: Selective alteration of the activity of the multiple forms of adenosine $3^{\prime}, 5^{\prime}$-monophosphate phosphodiesterase of rat cerebrum. Molec. Pharmacol., 10: 615 (1974).

49. Winick, M.: Changes in nucleic acid and protein content of the human brain during growth. Pediat. Res., 2: 352 (1968).

50. We are grateful to Drs. A. Mauer, M. Morrison, C. T. Huber, R. Gates, and L. King for their helpful comments and to the various physicians who enabled us to collect the tissues for study.

51. This study was supported in part by American-Lebanese-Syrian Associated Charities (ALSAC) and Grant HD-09469 from the National Institutes of Health, United States Public Health Service.

52. Requests for reprints should be addressed to: Ellen S. Kang, M.D., St. Jude Children's Research Hospital, 332 North Lauderdale St., Memphis, Tenn. 38101 (USA).

54. Accepted for publication September 30, 1976. 